\title{
PERSON DEIXIS AND SPATIAL DEIXIS OF KING DANGDUT BY RHOMA IRAMA SONGS
}

\author{
Yen-yen Natalia ${ }^{1}$, Iman Santoso ${ }^{2}$ \\ ${ }^{1}$ IKIP Siliwangi \\ ${ }^{2}$ IKIP Siliwangi \\ 1'yenyennatalis96@gmail.com, ${ }^{2}$ ImanSantoso515@gmail.com
}

\begin{abstract}
The aims of this research to find deixis and spatial deixis used of song lyrics from King of Dangdut by Rhoma Irama. Descriptive qualitative method used to collected data. The classified into type of deixis on the own criteria and the findings that the types of deixis like person deixis and spatial deixis used song lyrics of Rhoma irama. From the result, it can be concluded that person deixis and spatial deixis of finding and discussion is found in all song lyrics, personal deixis is the most being founding 81 words that is the word "Aku, Daku, $\mathrm{Ku}, \mathrm{Kamu}, \mathrm{Mu}$, and Nya, dominate all songs. The position is the spatial deixis 20 words. It can seen of the result analysis person deixis and spatial deixis can be many found in the six song lyrics.
\end{abstract}

Keywords: Person deixis, Spatial deixis, Music

\section{INTRODUCTION}

Music is the expression of language using rhythm which is now being much liked to many people in the world. The many of people that liked a music make many cover of the songs in the world although using first language or second language. According to Juslin and Sloboda (2010) music is the language emotions of persons that always to described through songs and singer by other people. Music is the song that made of result to the acts through sounds which is now to be hobbies or activities by other people. The element of subject music are rhythm, melodies, harmony, sctructure of the world, and expression of the singer.

Saarikalio (2010) said that music can be influence to mood and behavior. The most of music has be important for people life because can be achieve pleasure and experience mood that can help people to bring a nice atmosphere. Music has a relationship between lyric with meaning in the song because music contain to certain meanings for the listeners and depending of meaning in the song lyric that related with experience of listeners. Lyric is the one of expressions people about something that experience, heard, and views which is delivered throug song lyric. The experience to be show through expression use the play world and language to have a characteristic from creator of the song and interesting of listeners.

Rhoma Irama is singer of Dangdut have a good songs lyric and famous have meaning can be motivation for listeners. Rhoma was recorded to get 11 Golden Record of album and until now still call name is Raja Dangdut. This is as the reason of the researcher choose song lyric from Rhoma Irama to be object research. There are songs little will be object research follows: Judi, Ani, Bahtera Cinta, Keramat, Cuma kamu,Kegagalan Cinta. This songs is have language that containing of pragmatics. 
According to Santoso, et al (2014) Language fuction like a personal work of language, that is the speaker states the attitude towards what is presented. Language is the meaning of contextual that process studies to know meaning of the text through study pragmatics. Pragmatics is the learning aspect of contextual meaning from language that use it. However, depending of speaker, listener, and other thing of the context speech. According to Yule (1996:129-133) in Afrilian (2018) pragmatic is the study of entailment, implicature, presupposition, speech, and deixis. Based on the expert above that pragmatic is the part of language to study meanging of context speech that have been covers of fives aspect.

One of the branch in the pragmatic is deixis that indicating a word or phrase which conducting refers of objects, processes, attributes, and circumstances. An axpression in pragmatic is said to deixis if the phrase is alternately or depends on the context of advice. According to saeed (2003:182) in Nasution (2018) deixis is the word from "Deikymi" of classica Greek language which means "to showing or point out in the word of expression by the speaker". It is deixis very importance for people to poining expression during communication. Farahmand and Hatami (2012) said that Deixis is traditionally have been three types, there are spatial deixis, temporal deixis, and person deixis.

There are some expert said that type of deixis has five component that is person, deixis, spatial deixis, discourse deixis, time deixis, and sosial deixis. Language is an improvement for what dis say in the communication through expression deixis that depends of speakers and listeners. According to Levinson (1983) in Wowiling(2015) there are five types of deixis follows; person, deixis, spatial deixis, discourse deixis, time deixis, and sosial deixis. However, a researcher just take two of type deixis that is person deixis and spatial deixis, because type it is always often find in the song lyrics.

Lavinson (1983:152) in Turambi (2017) state that pesrson deixis is showing a form of a person's role in the language event when the phrases was spoken. It is important for expression a language through dexis that utterance or written. According to Kreidler (1998: 145) person deixis is relationship the basis of the speaker that familiar with pronouns. The pronouns that always find of the language which expression through deixis with utterance or written that implementasion by spoken.

According to Cruse (2006) in wati (2014) person deixis have a pronouns follows; I, You, Him, Mine, Yours, Her, Myself, Yourself, and Herself; then possessive adjective follows; My, your, and her. Deixis is consisting of fist person, second person, and third person. The first person is relate to the speaker reference himself. The second person is referring to the speaker reference to one or more on the one-time "You", and third person includes reference to someone or a group of people.

Spatial deixis is knowing a location expressions of the space relative to speaker (Kreidler, 1998: 145) in Hasanah (2016). It can seen of the expert is the locative expression can be known that symbol of spatial deixis in the language. Spatial deixis will be place if a speaker is standing and when the speaker said a place then there are listeners. Place deixis is kown as a space deixis that concerns locations with itself.

Spatial deixis is pointing of the location to some spaces between speaker and listener. Spatial deixis is show to relative of location people and thing like here and there. According to Lyons (2010) place or spatial deixis is the specification of location relative with concern to get points in the speech events. It's used pointing of location follows; now, tomorrow, today, yesterday. 
However, spatial deixis is mean isolasion because only use when know where is speaker to standing or what the speaker is indicat to be very meaningful.

\section{METHOD}

Qualitative method used in this research to found person deixis and spatial deixis of song lyrics from king Dangdut by Rhoma Irama. The characteristic of phenomenon from the song lyrics have a difference and data analyzed this uses description is not a number. According to Yin, (2011:3) qualitative researcher doing to design of study a real-world setting find how to overcome a problem and how to capture the context of the material presented. The data was taken from song lyrics in King of Dangdut by Roma Irama entitled which consists of six songs: Judi, Ani, Bahtera Cinta, Keramat, Cuma Kamu, and Kegagalan Cinta.

Knowing collected data that use listening in this research and there are steps to clearly this analysis, those steps are:

1. This steps download songs and lyrics which will be to analysis project.

2. Researcher listened a song lyrics to identification lyrics to know what is the word that use with detail.

3. After listening and identify of lyrics, researcher start to analyzed from song lyrics.

4. Marked words all of the chosen word in the song lyrics to be analyzed that related with person deixis and spatial deixis.

5. Researcher analysis every word to finding data to be collection of song lyrics. After collecting the data of song lyrics, the researcher analyzed the data follows:

1. Determine some words expressions that include in the person deixis and spatial deixis.

2. The researcher start to classified a word of the result an analysis to be determined based on their criteria.

3. Analyzed the data based on criteria of the result analysis to put in the table related person deixis and spatial deixis.

4. Researcher interpreted and described the analysis through descriptive qualitative.

\section{RESULTS AND DISCUSSION}

\section{Results}

The result of this research that is analysis six song lyrics of King of Dangdut by Rhoma Irama. There are Judi, Ani, Bahtera Cinta, Keramat, Cuma Kamu, and Kegagalan Cinta. The aim of analysis to knowing types of deixis which use in the song lyrics of King Dangdut in the language of Indonesian. Finally of analyze a songs to finding used two types of deixis in the song lyric included is person deixis and spatial deixis. There are one of the analyzing process to know frequency of found deixis, which can be seen on the table 1 .

Table 1. The total frequency of song lyrics from King of Dangdut by Rhoma Irama.

\begin{tabular}{clccc}
\hline No & Song Title & Person Deixis & Spatial Deixis & Total Frequency \\
\hline 1. & Judi & 2 & 0 & 2 \\
\hline 2. & Ani & 19 & 0 & 19 \\
\hline 3. & Bahtera Cinta & 6 & 4 & 10 \\
\hline 4. & Keramat & 21 & 8 & 29 \\
\hline 5. & Cuma Kamu & 20 & 6 & 26 \\
\hline \multirow{2}{*}{ 6. } & $\begin{array}{l}\text { Kegagalan } \\
\text { Cinta }\end{array}$ & 13 & 2 & 15 \\
\hline & Frequency & 81 & 20 & 101 \\
\hline
\end{tabular}


Based on the table above, the result of analysis song lyrics of Rhoma Irama with use person deixis and spatial deixis. There are 101 word that found of song lyrics that expression two type of deixis. However, type deixis of song lyrics king of Dangdut by Rhoma Irama is the most found of personal deixis with frequency is 81 words, while the spatial deixis just found frequency is 20 words.

Table 2. Examples of Person Deixis

\begin{tabular}{|c|c|}
\hline Title of The Song & Person Deixis \\
\hline Judi & $\begin{array}{l}\text { Bohong (bohong), kalaupun aku menang } \\
\text { Itu awal dari kekalahan }\end{array}$ \\
\hline Ani & $\begin{array}{l}\text { Sungguh aku tahu } \underline{\mathbf{k a u}} \text { cinta padaku } \\
\text { Ani Ani }\end{array}$ \\
\hline Bahtera Cinta & 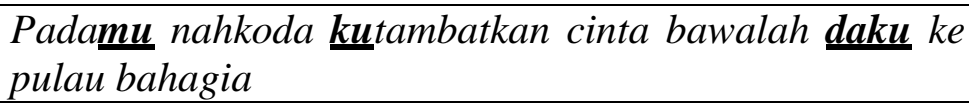 \\
\hline Keramat & $\begin{array}{l}\text { Yang melahirkan dan membesarkanmu, dari air susunva, } \\
\text { Bukan lautan tempat kau memuja }\end{array}$ \\
\hline Сита Кати & 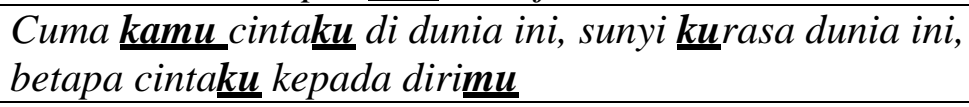 \\
\hline Kegagalan Cinta & 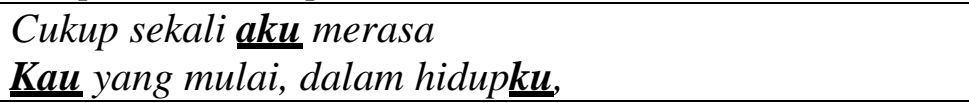 \\
\hline
\end{tabular}

It can see to the table above, there are many of word that found of song lyrics using person deixis in the first person, second person, and third person. The first person is the use pronoun $a k u, k u$, daku. However, the use of second person is found in the form possessive pronouns such as mu, nya, padamu, and padaku. The third person is recognized by the use word of gender that is Ani Ani.

Table 3. Examples of Place/Saptial Deixis

\begin{tabular}{lc}
\hline Title of The Song & Place Deixis \\
\hline Judi & - \\
\hline Ani & - \\
\hline Bahtera Cinta & $\begin{array}{c}\text { Berlayar bahtera mengharungi samudera } \\
\text { Mencapai tujuan nun } \underline{\text { di pantai harapan }}\end{array}$ \\
\hline Keramat & Bukannya gunung tempat kau meminta \\
Cuma Kamu & Cukan lautan tempat kau memuja sayangku di dunia ini \\
\hline Kegagalan Cinta & Di dalam hidupku \\
\hline
\end{tabular}

Based on analyze can see o the table above about position of spatial deixis or place deixis. the result found analyze is 20 words of all song lyrics by Rhoma Irama. The spatial deixis of lyrics song words is Samudera, Pantai harapan, Gunung, Tempat, Dunia, and hidup. It's result of shows frequently an analysis "judi, Ani and Bahtera Cinta" that less use person deixis and spatial deixis.

\section{Discussion}


The Discussion of the result of analysis, the data above that shows there are some song lyrics using person deixis and spatial deixis. However, the result of analysis song lyrics not many found a spatial deixis because a song lyrics sometime not say place in the songs. It can be seen of the table spatial deixis found 20 words in the six song lyrics of King Dangdut by Roma Irama. There are song lyrics from King Dangdut that use spatial dexis or place. However, many song from creator of the song that use spatial deixis in the lyric.

The result of the analysis about person deixis, it can seen in the table above found 81 words in the six song lyrics. The type of deixis that often found in the song lyrics, not wonder many found of result analysis in the song lyrics of king Dangdut. Language that expression although part of pragmatic that use speaker and listener in the song lyrics of King Dangdut in Indonesia. Person deixis and spatial deixis that found 101 words of all song lyrics King Dangdut Rhoma Irama.

\section{CONCLUSION}

The conclusion of this research is knowing contextual meaning of language through study pragmatics. The branch of pragmatic is deixis that indicating a word or phrase which conducting refers of objects, processes, attributes, and circumstances. There are part of deixis that use to analysis song lyrics of King Dangdut by Rhoma Irama. Based on the result of analysis, in the song lyrics there are found person deixis and spatial deixis. Person deixis is showing of the person between speaker and listener. Spatial deixis is pointing of the location to some spaces between speaker and listener. The found of analyze abaout person deixis and spatial deixis is 101 words.

\section{ACKNOWLEDGMENTS}

Thanks to Allah SWT that always help me when to be finish of this project and thanks to Mr. Iman Santoso as a supervisor for me during prepare this project. Thanks also for my parent and friend is Khusni Rahayu as ancouragement to help the achievement of spirit to finish this project. I hope the result of this research can be help to researcher in project analysis and to be reference in the project. The aim of this reseach I hope to criticism and suggestions from reader for better to the front when make a project again.

\section{REFERENCES}

Afrilian, W. (2018). Deixis In Judith Mcnaught's Night Whispers Novel. Abad And Humanities Faculty The State Islamic University Sulthan Thaha Saifuddin Jambi: Thesis.

Elsaria, S. \& Herman. (2019). A Deixis Analysis Of Song Lyrics In Calum Scott "You Arethe Reason". Internasional Journal Of Science Publising Group, 24-28.

Hasanah, U. (2016). A Pragmatic Study On Deixis In The Song Lyrics Of Harris J's "Salam" Album. English Language And Letters Departement Humanities Faculty State Islamic University Maulana Malik Ibrahim Malang : Thesis.

Nasution, D. R. A., Et Al (2018). Deixis Analysis In The Song Lyrics Of Ed Sheeran's. English Language And Literature International Conference (Ellic), 381-382.

Rahmi, D. H. (2018). A Pragmatict Study On Deixis In The Song's Lyric Of Deen Squad Album. Faculty Of Education And Teacher Training Ar-Raniry State Islamic University Darussalam Banda Aceh : Thesis.

Santoso, I., Et Al (2014). Speech Act On Short Stories; A Pragmatic Study . International Journal Of Social Sciences , 116-118. 
Turambi, F. S. (2017). Deiksis Dalam Film Be Before You Karya Alison Owen (Suatu Analisis Pragmatik). Universitas Sam Ratulangi Fakultas Ilmu Budaya Manado: Jurnal Skripsi.

Wati, D. R. (2014). A Deixis Analysis Of Song Lyrics In Taylor Swift's "Red" Album. Inglish Letters Department Adab And Humanities Faculty State Islamic University Syarif Hidayatullah Jakarta: A Thesis.

Wowiling, M. (2015). Deiksis Dalam Novel The Notebook Karya Nicholas Sparks (Suatu Analisis Pragmatik). Universitas Sam Ratulangi Fakultas Ilmu Budaya Manado: Jurnal Skripsi. 